\title{
Estimation of Genetic Variability for Yield and Yield Related Traits in Tomato (Solanum lycopersicum L.) under Polyhouse Condition
}

\author{
Ankit Panchbhaiya*, Dinesh Kumar Singh, Priyanka Verma and Sanganamoni Mallesh \\ Department of Vegetable Science, Govind Ballabh Pant University of Agriculture and \\ Technology, Pantnagar (Uttarakhand), India \\ *Corresponding author
}

\begin{tabular}{|c|}
\hline Keywords \\
\hline $\begin{array}{l}\text { GCV, Genetic } \\
\text { variability, Genetic } \\
\text { advance, Heritability, } \\
\text { PCV, Tomato }\end{array}$ \\
\hline Article Info \\
\hline $\begin{array}{l}\text { Accepted: } \\
10 \text { August } 2018 \\
\text { Available Online: } \\
10 \text { September } 2018\end{array}$ \\
\hline
\end{tabular}

\section{Introduction}

Tomato (Solanum lycopersicum L.) is an important vegetable of Solanaceae family having chromosome number $2 n=2 x=24$. It has originated from wild form in the PeruEquador-Bolivia region of the Andes, South America (Rick, 1969) and is grown in almost every corner of the world (Roberston and Labate, 2007). It is one of the most popular and widely grown vegetable in the world ranking second in importance to potato in many countries. Tomato is one of the most
The present investigation was carried out on thirty six genotypes of tomato for genetic variability assessment. The analysis of variance revealed that significant genetic differences were present among the tomato genotypes for all the traits studied. High GCV and PCV estimates were observed for number of fruits per plant, average fruit weight, fruit yield per hectare, fruit yield per plant, number of flowers per cluster and number of fruits per cluster. Number of fruits per plant recorded maximum heritability followed by average fruit weight, number of flowers per cluster, number of fruits per cluster, fruit length, days to first fruit ripening, fruit yield per plant, fruit yield per hectare, fruit width, 100 seed weight and days to first fruit set. High estimates of genetic advance as percentage of mean observed for number of fruits per plant, average fruit weight, fruit yield per hectare, per plant, number of flowers per cluster, number of fruits per cluster, fruit length, fruit width, 100 seed weight, fruit shape index and internodal length. Therefore, selection for these characters in segregating generations based on phenotypic performance would likely be more effective for further improvement in tomato. 
tomato is the first crop grown in polyhouse worldwide. Demand for tomatoes is usually strong due to the vine-ripe nature and general overall high level of eating quality. Selection of the most suitable cultivar is a pre-requisite for successful tomato cultivation in a greenhouse. The important characteristics related to cultivars include high fruit yield, high number of fruits, good shelf life, high TSS, disease resistance and freedom from cracking and green shoulder. Consumer's preference with respect to size, shape and colour of the variety also plays an important role in varietal selection.

The efficiency of selection largely depends upon the magnitude of variability present in the breeding population. Hence, knowledge of variability present in the gene pool of a crop species is essential to start a judicious breeding programme. Earlier variability used to be assessed by visual observation. Now biometrical methods are available for systematic assessment of genetic variability. Keeping this in view, the present investigation was aimed at assessing the genetic variability among thirty six genotypes of tomato.

\section{Materials and Methods}

The experiment was conducted at Vegetable Research Centre (V.R.C.), Govind Ballabh Pant University of Agriculture \& Technology, Pantnagar, Uttarakhand during the year 201718. This university is situated in the foot hills of Shivalik range of Himalayas in the narrow belt called 'Tarai'. Geographically, it is situated at an altitude of $243.84 \mathrm{~m}$ above mean sea level, and between $29.50^{\circ}$ North latitude and $79.30^{\circ}$ East longitude. The climate of the region is broadly humid subtropical with cool winter and hot dry summer. The soil of experimental field was sandy-loam with adequate drainage and optimum water holding capacity. The experimental material for this study consists of 36 genotypes of tomato.
Five competitive plants from each entry in each replication were randomly selected before flowering and tagged for the purpose of recording observations on different quantitative traits and their average values were used in the statistical analysis. The genotypes were studied for fifteen yield related traits viz., days to 50 per cent flowering, days to first fruit set, days to first fruit ripening, number of flowers per cluster, number of fruits per cluster, number of fruits per plant, internodal length $(\mathrm{cm})$, average fruit weight $(\mathrm{g})$, fruit length $(\mathrm{cm})$, fruit width $(\mathrm{cm})$, fruit shape index, plant height $(\mathrm{cm}), 100$ seed weight $(\mathrm{g})$, fruit yield per plant $(\mathrm{kg})$ and fruit yield per hectare (t/ha), The analysis of variance for design of experiment was done for partitioning the variance into treatments and replications according to procedure given by Panse and Sukhatme (1967). Genotypic and phenotypic coefficients of variance were estimated according to Burton and Devane (1953) based on estimate of genotypic and phenotypic variance.

The broad sense heritability $\left(h^{2} b s\right)$ was estimated by following the procedure suggested by Weber and Moorthy (1952). Genetic advance as per cent of mean was categorized as low, moderate and high as given by Johnson et al., (1955).

\section{Results and Discussion}

Mean data of fifteen yield related traits were subjected to Analysis of variance (ANOVA) for Randomized Block Design (RBD) is presented in Table 1. The mean sum of square due to treatments was found highly significant for all yield related traits under study at $1 \%$ and $5 \%$ level of significance, which indicated that considerable amount of variability were present in the genotypes included in the study. Hence, there is ample scope for selection of promising genotypes in breeding programme for yield related traits. Similar results with 
respect to analysis of variance also reported by Narolia et al., (2012), Agarwal et al., (2014), Reddy et al., (2014), Singh et al., (2014), Prajapati et al., (2015), Kumar and Singh (2016), Kumar et al., (2017a) and Kumar et al., (2017b).

Effectiveness of any selection programme depends upon the existence of genetic variability present within the population. The assessment of genetic variability present in a given crop population can be determined by using the biometrical components such as range, variance, coefficient of variation, standard error and heritability.

Phenotypic coefficient of variation (PCV) and genotypic coefficient of variation (GCV) are the best criteria to measure available variability. Heritability of a character is important in determining its response to selection. Genetic improvement of plants for quantitative traits requires reliable estimates of heritability in order to plan an effective breeding program.

Assessment of variability parameters revealed that there is lot of variation present among the genotypes studied. In general, the value of phenotypic coefficient of variation (PCV) was higher than the genotypic coefficient of variation $(\mathrm{GCV})$ for all the characters studied in the present findings, indicating the considerable influence of environmental factors on the performance of genotypes for different characters.

Similar results were also reported in tomato by Premalakshmi et al., (2014), Rai et al., (2016), Kumar et al., (2017a) and Kumar et al., (2017b).

Data presented in Table 2 revealed that high GCV and PCV estimates were observed for many traits viz., number of fruits per plant (97.64 and 98.98\%), average fruit weight
(40.64 and 41.31\%), fruit yield per hectare (34.76 and $36.65 \%$ ), fruit yield per plant (34.75 and $36.64 \%$ ), number of flowers per cluster (30.37 and $31.17 \%$ ) and number of fruits per cluster (26.74 and 27.60\%). Moderate to high GCV and PCV was observed in fruit length (19.99 and 20.74\%) and fruit width (19.60 and 21.17\%).

Moderate to high GCV and PCV for these traits clearly indicate ample scope for yield improvement in tomato through selection due to the presence of sufficient variability genotypes studied. The GCV and PCV were low for days to first fruit ripening (6.64 and $6.94 \%$ ), days to first fruit set (7.80 and $8.98 \%$ ) and days to 50 per cent flowering (9.59 and $11.62 \%$ ) whereas, moderate for fruit shape index (15.02 and 18.20\%), 100 seed weight (13.82 and 14.97\%) internodal length (13.64 and $16.11 \%)$ and plant height (12.01 and $15.99 \%)$.

The results of the present investigation agreed with the finding of Islam et al., (2012), Saleem et al., (2013), Singh et al., (2014), Pujer et al., (2015), Kumar and Singh (2016), Kumar et al., (2017b) and Kaushal et al., (2017).

Broad sense heritability estimates ranged from 56.37 per cent (Plant height) to 97.31 per cent (Number of fruits per plant) (Table 2).

Number of fruits per plant recorded maximum heritability $(97.31 \%)$ followed by average fruit weight $(96.80 \%)$, number of flowers per cluster $(94.95 \%)$, number of fruits per cluster $(93.86 \%)$, fruit length $(92.89 \%)$, days to first fruit ripening $(91.51 \%)$, fruit yield per plant $(89.97 \%)$, fruit yield per hectare $(89.97 \%)$, fruit width $(85.72 \%), 100$ seed weight $(85.26 \%)$ and days to first fruit set $(75.57 \%)$. The heritability estimates for these traits indicate that these characters are least influenced by the environment. 
Table.1 Analysis of variance for fifteen yield related traits in tomato

\begin{tabular}{|c|l|c|c|c|}
\hline \multirow{2}{*}{ S. N. } & \multicolumn{1}{|c|}{ Characters } & \multicolumn{3}{|c|}{ Mean sum of squares } \\
\cline { 3 - 5 } & & Replication & Genotype & Error \\
\hline $\mathbf{1}$ & Days to 50 per cent flowering & $\mathbf{2}$ & $\mathbf{3 5}$ & $\mathbf{7 0}$ \\
\hline $\mathbf{2}$ & Days to first fruit set & 25.482 & $40.012^{* *}$ & 5.415 \\
\hline $\mathbf{3}$ & Days to first fruit ripening & 0.190 & $48.642^{* *}$ & 4.732 \\
\hline $\mathbf{4}$ & Number of flowers per cluster & 0.889 & $46.107^{* *}$ & 2.882 \\
\hline $\mathbf{5}$ & Number of fruits per cluster & 0.073 & $12.547^{* *}$ & 0.775 \\
\hline $\mathbf{6}$ & Number of fruits per plant & 60.911 & $8,771.391^{* *}$ & 0.268 \\
\hline $\mathbf{7}$ & Internodal length & 0.126 & $7.068^{* *}$ & 79.967 \\
\hline $\mathbf{8}$ & Average fruit weight & 168.874 & $3,880.309^{* *}$ & 0.821 \\
\hline $\mathbf{9}$ & Fruit length & 0.108 & $2.774^{* *}$ & 0.069 \\
\hline $\mathbf{1 0}$ & Fruit width & 0.116 & $2.490^{* *}$ & 0.131 \\
\hline $\mathbf{1 1}$ & Fruit shape index & 0.021 & $0.089^{* *}$ & 0.012 \\
\hline $\mathbf{1 2}$ & Plant height & 577.632 & $8,026.012^{* *}$ & $1,646.279$ \\
\hline $\mathbf{1 3}$ & 100 seed weight & 0.0005 & $0.0076^{* *}$ & 0.0004 \\
\hline $\mathbf{1 4}$ & Fruit yield per plant & 0.0005 & $5.051^{* *}$ & 0.181 \\
\hline $\mathbf{1 5}$ & Fruit yield per hectare & 0.833 & $6,255.634^{* *}$ & 224.116 \\
\hline
\end{tabular}

* Significant at $5 \%$ level of probability

** Significant at $1 \%$ level of probability

Table.2 Estimation of genetic components and other genetic parameters for different yield related traits in tomato

\begin{tabular}{|r|l|c|c|c|c|c|c|c|}
\hline S.N. & \multicolumn{1}{|c|}{ Characters } & Range & $\begin{array}{c}\text { General } \\
\text { Mean }\end{array}$ & GCV & PCV & ECV & $\begin{array}{c}\text { Heritabilit } \\
\text { y }(\mathbf{\%})\end{array}$ & $\begin{array}{c}\text { GA as \% } \\
\text { of mean }\end{array}$ \\
\hline $\mathbf{1}$ & Days to 50 per cent flowering & $30.33-43.67$ & 35.43 & 9.59 & 11.62 & 6.57 & 68.05 & 16.29 \\
\hline $\mathbf{2}$ & Days to first fruit set & $43.00-57.47$ & 49.03 & 7.80 & 8.98 & 4.44 & 75.57 & 13.97 \\
\hline $\mathbf{3}$ & Days to first fruit ripening & $\mathbf{6 8 . 2 0 - 9 5 . 1 3}$ & 84.01 & 6.64 & 6.94 & 2.02 & 91.51 & 13.08 \\
\hline $\mathbf{4}$ & No. of flowers per cluster & $7.67-26.40$ & 12.56 & 30.37 & 31.17 & 7.01 & 94.95 & 60.96 \\
\hline $\mathbf{5}$ & No. of fruits per cluster & $5.47-14.80$ & 7.57 & 26.74 & 27.60 & 6.84 & 93.86 & 53.36 \\
\hline $\mathbf{6}$ & No. of fruits per plant & $27.39-355.73$ & 55.12 & 97.64 & 98.98 & 16.22 & 97.31 & 198.43 \\
\hline $\mathbf{7}$ & Internodal length & $7.80-13.40$ & 10.58 & 13.64 & 16.11 & 8.56 & 71.72 & 23.80 \\
\hline $\mathbf{8}$ & Average fruit weight & $9.90-159.93$ & 88.00 & 40.64 & 41.31 & 7.39 & 96.80 & 82.38 \\
\hline $\mathbf{9}$ & Fruit length & $2.11-6.55$ & 4.75 & 19.99 & 20.74 & 5.53 & 92.89 & 39.68 \\
\hline $\mathbf{1 0}$ & Fruit width & $1.83-6.35$ & 4.52 & 19.60 & 21.17 & 8.00 & 85.72 & 37.39 \\
\hline $\mathbf{1 1}$ & Fruit shape index & $0.86-1.66$ & 1.07 & 15.02 & 18.20 & 10.27 & 68.14 & 25.55 \\
\hline $\mathbf{1 2}$ & Plant height & $236.13-448.67$ & 384.05 & 12.01 & 15.99 & 10.56 & 56.37 & 18.57 \\
\hline $\mathbf{1 3}$ & 100 seed weight & $0.13-0.42$ & 0.35 & 13.82 & 14.97 & 5.75 & 85.26 & 26.29 \\
\hline $\mathbf{1 4}$ & Fruit yield per plant & $1.34-6.83$ & 3.67 & 34.75 & 36.64 & 11.60 & 89.97 & 67.90 \\
\hline $\mathbf{1 5}$ & Fruit yield per hectare & $47.27-240.37$ & 129.00 & 34.76 & 36.65 & 11.61 & 89.97 & 67.92 \\
\hline
\end{tabular}


Internodal length $(71.72 \%)$, fruit shape index (68.14\%), days to 50 per cent flowering $(68.05 \%)$ and plant height $(56.37 \%)$ exhibited moderate level of heritability. However, low heritability $(<50 \%)$ was not observed for any character. Low to moderate estimates of broad sense heritability indicates that these characters are highly influenced by environmental effects and the genetic improvement through selection in these traits is difficult due to masking effect of environment on the genotypic effects.

High estimates of genetic advance as percentage of mean $(>20 \%)$ was observed for most of the characters under study viz., number of fruits per plant (198.43\%), average fruit weight $(82.38 \%)$, fruit yield per hectare (67.92\%), fruit yield per plant (67.90), number of flowers per cluster $(60.96 \%)$, number of fruits per cluster $(53.36 \%)$, fruit length (39.68\%), fruit width (37.39\%), 100 seed weight (26.29\%), fruit shape index (25.55\%) and internodal length (23.80\%). High estimates of genetic advance as percentage of mean indicated that the preponderance of additive genetic effects in expression of these characters. Therefore, selection for these characters in segregating generations based on phenotypic performance would likely be more effective.

Moderate level of genetic advance as percentage of mean (10-20\%) were observed for plant height (18.57\%), days to 50 per cent flowering (16.29\%), days to first fruit set $(13.97 \%)$ and days to first fruit ripening $(13.08 \%)$.

High heritability does not always mean high genetic advance. For yield improvement, selection of superior parents possessing better heritability and genetic advance for yield contributing traits is an essential prerequisite. Heritability in conjunction with genetic advance determines the best picture of the amount of progress to be expected from selection and also the selection method to improve a character (Johnson et al., 1955).

Based on the underlying facts, the traits under study were categorized into four different groups as per the analysis: First group included majority of the characters under study exhibited high estimates of broad sense heritability and high estimates of genetic advance as percentage of mean viz. number of flowers per cluster, number of fruits per cluster, number of fruits per plant, average fruit weight, fruit length, fruit width, 100 seed weight, fruit yield per plant and fruit yield per hectare.

High heritability and high genetic advance estimates for these characters indicated that these traits were less affected by environmental factors. This strongly indicated the preponderance of additive gene action involved in the expression of these characters and hence, there exists an ample scope for the improvement of concerned traits through direct selection. The second group of traits included days to first fruit set and days to first fruit ripening, which had high heritability estimates coupled with moderate genetic advance as per cent of mean. The third group consisted internodal length and fruit shape index which had moderate heritability coupled with high genetic advance. The fourth group included days to 50 per cent flowering and plant height which had moderate heritability estimates coupled with moderate genetic advance as per cent of mean.

For different characters, similar results were also observed by various researchers like Agarwal et al., (2014), Mukul et al., (2014), Premalakshmi et al., (2014), Kumar et al., (2016), Nalla et al., (2016), Rai et al., (2016), Kumar et al., (2017a) and Kaushal et al., (2017). 
Thus, based on the findings of present investigation, it can be concluded that sufficient quantum of genetic variability was generated involving diverse genotypes of tomato, which indicates the existence of considerable scope for the improvement of these genotypes through selection and hybridization. Furthermore, moderate to high GCV together with moderate to high heritability and genetic advance as per cent of mean was reported for majority of the characters under study except characters related to earliness which indicated predominant additive gene action thus these traits has ample scope for the improvement of concerned traits through selection.

\section{References}

Agarwal, A., Arya, D. N. and Ahmed, Z. 2014. Genetic variability studies in tomato (Solanum lycopersicum L.). Progressive Horticulture, 46(2): 358361.

Burton G. W. and Devane E. M. 1953. Estimating heritability in tall fescue (Festuca arundinacea) from replicated clonal material. Agron. J., 45: 478-481.

Islam, M. S., Mohanta, H. C., Ismail, M. R., Rafii, M. Y. and Malek, M. A. 2012. Genetic variability and trait relationship in cherry tomato (Solanum lycopersicum L. var. cerasiforme (Dunnal) A. Gray). Bangladesh Journal of Botany, 41(2): 163-167.

Johnson, H. W., Robinson, H. F. and Comstock, R. S., 1955. Estimation of genetic and environmental variability in soyabean. Agron. J., 41: 314-318.

Kaushal, A., Singh, A., Chittora, A., Nagar, L., Yadav, R. K. and Kumawat, M. K. 2017. Variability and correlation study in tomato (Solanum lycopersicum L.). International Journal of Agriculture Sciences, 9(29): 4391-4394.
Kumar M., Yadav R. K., Yadav R. K., Behera T. K. and Talukdar A. 2017b. Estimates of genetic variability, heritability and genetic advance for yield and yield component traits in thermo tolerant tomato (Solanum lycopersicum L.) genotypes. International Journal of Agriculture Sciences. 9(2): 3640-3642.

Kumar P. P., Sathish V., Ramesh D., Bhutia N. D., Koundinya A. V. V. and Hazra P. 2016. Assessment of genetic variability, correlation and path coefficients for yield components and quality traits in tomato. International Journal of Agriculture Sciences, 8(54): 2870-2873.

Kumar, S. and Singh, A. 2016. Assessment of genetic variability, character association and path analysis in tomato ( $S$. lycopersicum L.) under tarai condition of Uttarakhand. International Journal of Agriculture Sciences, 8(34): 1706-1709.

Kumar, S., Singh, V., Maurya, P. K., Kumar, B. A. and Yadav, P. K. 2017a. Evaluation of $\mathrm{F}_{1}$ hybrids along with parents for yield and related characteristics in tomato (Solanum lycopersicum Child). Int. J. Curr. Microbiol. App. Sci, 6(9): 2836-2845.

Mukul, Vishal, K., Agrawal, K., Srivastava and Agrawal, R. K. 2014. Heritable and non heritable components of phenotypic correlation coefficient and path analysis in tomato (Solanum lycopersicum L.). The Bioscan, 9(4): 1789-1793.

Nalla, M. K., Pandav, A. K., Aslam, T. and Rana, M. K. 2016. Studies on variability, heritability and genetic advance in tomato (Solanum lycopersicon L.). Advances in Life Sciences, 5(4): 1536-1539.

Narolia, R. K., Reddy, R. V. S. K. and Sujatha, M. 2012. Genetic architecture of yield and quality in tomato (Solanum lycopersicum). Agricultural Science Digest, 32(4): 281-285. 
Panse, V. G. and Sukhatme, P. V. 1967. Statistical method for Agricultural workers. $4^{\text {th }}$ Edn., ICAR, New Delhi.

Prajapati, S., Tiwari, A., Kadwey, S. and Jamkar, T. 2015. Genetic variability, heritability and genetic advance in tomato (Solanum lycopersicon Mill.). International Journal of Agriculture, Environment and Biotechnology, 8(2): 245-251.

Premalakshmi, V., Kumar; S. R. and Arumugam, T. 2014. Evaluation and genetic studies in tomato genotypes, Trends in Biosciences, 7(13): 14071410.

Pujer, P., Jagadeesha, R. C. and Suresh. 2015. Genetic variability \& correlation studies in cherry tomato (Solanum lycopersicum L. var. cerasiforme Mill.). Green Farming, 6(1): 30-32.

Rai, A. K., Vikram, A. and Pandav, A. 2016. Genetic variability studies in tomato (Solanum lycopersicum L.) for yield and quality traits. International Journal of Agriculture, Environment and Biotechnology, 9(5): 739-744.

Reddy, B. R., Begum, H., Reddy, M. A., Sunil, A. and Reddy, M. P. 2014. Genetic variability and effect relationship for yield \& quantitative traits in exotic lines of tomato. Green Farming, 5(1): 104-107.

Rick, C. M. 1969. Origin of cultivated tomato, current status and the problem. Abstract, XI International Botanical Congress, 180.

Robertson, L. D. and Labate, J. A. 2007. Genetic resources of tomato ( $L$. esculentum Mill.) and wild relatives. In: Razdan, M. K., Matoo, A. K. (eds.) Genetic improvement of solanaceous crops, 2: Tomato, Sci. Publishers, New Hampshire, USA.

Saleem, M. Y., Iqbal, Q. and Asghar, M. 2013. Genetic variability, heritability, character association and path analysis in $\mathrm{F}_{1}$ hybrids of tomato. Pakistan Journal of Agricultural Sciences, 50(4): 649-653.

Singh, V., Naseeruddin, K. H. and Rana, D. K. 2014. Genetic variability of tomato genotypes for yield and other horticultural traits. J. Hill. Agri., 5(2): 186-189.

Weber, C. R. and Moorthy, H. R., 1952. Heritable and non- heritable relationship and variability of oil content and agronomic characters in the $F_{2}$ generation of soyabean crosses. Agron. J., 44: 202-209.

\section{How to cite this article:}

Ankit Panchbhaiya, Dinesh Kumar Singh, Priyanka Verma and Sanganamoni Mallesh. 2018. Estimation of Genetic Variability for Yield and Yield Related Traits in Tomato (Solanum lycopersicum L.) under Polyhouse Condition. Int.J.Curr.Microbiol.App.Sci. 7(09): 1553-1559. doi: https://doi.org/10.20546/ijcmas.2018.709.186 